\title{
Current status of national integrated gasification fuel cell projects in China
}

\author{
Suping Peng ${ }^{1}$
}

Received: 20 July 2020/Revised: 1 February 2021 / Accepted: 20 May 2021 / Published online: 3 July 2021

(C) The Author(s) 2021

\begin{abstract}
Coal has been the main energy source in China for a long period. Therefore, the energy industry must improve coal power generation efficiency and achieve near-zero $\mathrm{CO}_{2}$ emissions. Integrated gasification fuel cell (IGFC) systems that combine coal gasification and high-temperature fuel cells, such as solid oxide fuel cells or molten carbonate fuel cells (MCFCs), are proving to be promising for efficient and clean power generation, compared with traditional coal-fired power plants. In 2017, with the support of National Key R\&D Program of China, a consortium led by the China Energy Group and including 12 institutions was formed to develop the advanced IGFC technology with near-zero $\mathrm{CO}_{2}$ emissions. The objectives of this project include understanding the performance of an IGFC power generation system under different operating conditions, designing master system principles for engineering optimization, developing key technologies and intellectual property portfolios, setting up supply chains for key materials and equipment, and operating the first megawatt IGFC demonstration system with near-zero $\mathrm{CO}_{2}$ emission, in early 2022. In this paper, the main developments and projections pertaining to the IGFC project are highlighted.
\end{abstract}

Keywords Integrated gasification fuel cell (IGFC) $\cdot$ Fuel cell $\cdot$ Coal-based power generation $\cdot$ Near-zero $\mathrm{CO}_{2}$ emissions

\section{Introduction}

Coal is the most abundant and low-cost energy carrier on the planet. This makes coal the dominant source for energy as well as greenhouse gas emissions (Wang et al. 2015; Chang et al. 2016; Li et al. 2018). The major greenhouse gases include $\mathrm{CO}_{2}$, methane, and nitrous oxide $\left(\mathrm{N}_{2} \mathrm{O}\right)$. Of these, $\mathrm{CO}_{2}$ levels have increased by more than $40 \%$ since the beginning of the Industrial Revolution, from about 280 parts per million (ppm) in the 1800 s to $400 \mathrm{ppm}$ today; most of this increase was caused by burning coal. The emission of greenhouse gases leads to global warming, climate change, rising sea levels, decreasing ocean $\mathrm{pH}$, and

Suping Peng

psp@cumtb.edu.cn

1 Research Center of Solid Oxide Fuel Cell, State Key Laboratory of Coal Resource and Safety Mining, China University of Mining and Technology-Beijing, Beijing 100083, China extreme weather events. The adverse effects caused by global warming require greater power efficiency and lower $\mathrm{CO}_{2}$ emission for traditional coal-fired power plants (pulverized coal-fired boilers (Bhanarkar et al. 2008; Mao et al. 2014)). In November 2018, the US Department of Energy announced the "Coal FIRST" plan, aimed at developing flexible, innovative, resilient, small, and transformative advanced coal-fired power plants suitable for future energy systems. In May 2019, the US Department of Energy (2019) invested US $\$ 100$ million in this plan to develop future advanced coal power plants.

Integrated gasification combined cycle (IGCC) power generation systems were designed for higher efficiency and lower $\mathrm{CO}_{2}$ emissions. The first generation of IGCC systems was developed in the 1970s to mitigate the oil crisis. Commercial IGCC systems were demonstrated in the 1990s (Gräbner 2015). In 2009, the China Huaneng Group launched the first 250-MW-class IGCC demonstration power plant. In 2012, the gasifier was successfully ignited, leading to the generation of electricity. To date, the system 
has reached $41 \%$ (lower heat value, LHV) efficiency in operation (Jiao 2009; Lv et al. 2010; Hui 2015). Dry coal powder gasification is one of the key technologies utilized in IGCC systems. Although commercial gasifiers are available, the gasification efficiency, syngas purification, and cost reduction require further research and development.

Fuel cell technology has attracted considerable attention for decades. The fuel cell is an electrochemical device that can directly convert chemical energy into electricity. The integrated gasification fuel cell (IGFC) power generation system combines coal gasification and high-temperature fuel cells, such as solid oxide fuel cells (SOFCs) or molten carbonate fuel cells (MCFCs). The IGFC is able to achieve much greater system efficiency, up to 50\%-60\%, and lower cost for $\mathrm{CO}_{2}$ capture and utilization, and is a revolutionary breakthrough compared with traditional coal-based power generation, which relies on the combustion of coal to generate electricity with lower efficiency (Peng and Han 2009; Li et al. 2010; Discepoli et al. 2012). The technology of IGFCs makes near-zero emissions of $\mathrm{CO}_{2}$ and pollutants more feasible. In 2000, a study by the Solid State Energy Conversion Alliance (SECA) showed that, by using internal $\mathrm{CO}_{2}$ capture in fuel cells, the economic and environmentally friendly IGFC system could capture $99 \% \mathrm{CO}_{2}$ before emission (Surdoval et al. 2001).

Both the US Department of Energy (DOE) and Japan's New Energy and Industrial Technology Development Organization (NEDO) have been supporting IGFC technology development and application demonstration for some time (Williams et al. 2006; Damo et al. 2019). In 2000, the US DOE established the SECA program to develop 100 MW IGFC systems (Dong et al. 2019). In 2003, a megawatt IGFC power generation system was demonstrated at Wabash River Generating Station by Kentucky Advanced Energy and Fuel Cell Energy. In 2016, the US National Energy Technology Laboratory made medium- and long-term development plans for SOFC technology. Based on the plans, $10 \mathrm{MW}$ and $50 \mathrm{MW} \mathrm{IGFC}$ or natural gas fuel cell demonstration systems with carbon capture would be built in 2025 and 2030, respectively.

In 2015, Japan announced a 10 year IGFC development plan with the goal of achieving $55 \%$ power generation efficiency by 2025 (Dong et al. 2019). Since 2017, NEDO and Osaki Power Generation Co. Ltd. have cooperated on an IGFC verification project. The project included three phases: (1) oxygen-rich IGCC system verification; (2) verification of the IGCC system with near-zero $\mathrm{CO}_{2}$ emission; and (3) verification of the IGFC system with near-zero $\mathrm{CO}_{2}$ emission. The third phase was started in 2019 with two $600 \mathrm{~kW}$ IGFC systems. The goal of the phase 3 program is to achieve $47 \%$ power efficiency with $90 \% \mathrm{CO}_{2}$ recovery rate. This technology would be applied to 500-MW-class commercial power generation facilities in the future (Shindo 2017). In August 2018, Minister Wang Zhigang of China's Ministry of Science and Technology visited the International Research Center for Hydrogen Energy at Kyushu University and the $250 \mathrm{~kW}$ fuel cell demonstration system in Japan. The development of IGFC technology in China is in its very early stages. In 2009, Peng proposed the development of IGFC technology in China (Peng and Han 2009). Later, a novel concept that combined coal gasification, SOFCs, and chemical looping combustion was formulated and evaluated. Based on the model analysis, the net power efficiency of the system is projected to reach $49.8 \%$ (based on coal LHV, including energy penalties for coal gasification, oxygen production, and $\mathrm{CO}_{2}$ compression) (Chen et al. 2015).

The IGFC system with near-zero $\mathrm{CO}_{2}$ emissions integrates coal gasification, high-temperature fuel cells, and $\mathrm{CO}_{2}$ capture and utilization. With the support of the Ministry of Science and Technology of China, Chinese researchers proceeded to the design, manufacture, and operation of large-scale coal gasification technology. The system integration design and optimization, operation, and control technology should be finished during the periods of the 10th, 11th, and 12th Five-Year Plans. These will build a solid foundation for further development of IGFC technology. Currently, the development and commercialization of IGFCs has been considered a strategic energy plan by the Chinese government. In the "13th Five-Year Plans for Power Development", there is expected to be a technology breakthrough in improving the efficiency of traditional coal-fired power plants. The development and application of fuel cell technology in stationary power generation systems are also expected.

High-temperature fuel cells, especially SOFCs, are the most promising technology for use in IGFC systems. Fuel Cell Energy, Bloom Energy, Mitsubishi Heavy Industries, and Siemens Westinghouse have demonstrated SOFCs for stationary power generation. Nowadays, SOFC technology is in the early stages of commercialization. The near-term objective is to reduce costs and improve the performance and long-term stability of the SOFC systems (Mastropasqua et al. 2017; Damo et al. 2019). Using SOFC systems, good progress was also made in $\mathrm{CO}_{2}$ enrichment for carbon capture and storage; $90 \%$ and $95 \%$ of $\mathrm{CO}_{2}$ enrichment has been achieved in gas turbine SOFCs (Campanari 2002) and IGFC systems (Li et al. 2012), respectively.

The development of high-temperature fuel cells in China falls behind that in leading countries. Chinese researchers have completed the "Basic research on carbon-based solid oxide fuel cell" program under the "973" project and a kilowatt-class SOFC power generation unit has been successfully developed. However, the remaining challenge is 
to scale up the smaller SOFC unit to build a larger power generation system. In July 2017, the China Energy Group received an award from the Ministry of Science and Technology under the National Key R\&D Program for a program to develop "Integrated gasification fuel cell technology with near-zero $\mathrm{CO}_{2}$ emission." To complete this project, an industry-university research team was formed, led by the China Energy Group, and including a total of 12 universities, research institutes, and industrial partners, such as the China University of Mining and Technology-Beijing, the China Huaneng Group, and the National Institute of Clean and Low-Carbon Energy. The team has been focusing on key scientific problems and technologies related to IGFCs, such as coal gasification techniques, syngas cleaning processes, high-temperature fuel cell stack and module design, fuel cell system integration and design concepts, and $\mathrm{CO}_{2}$ capture and utilization. This team is technology innovation-oriented, and the objective of the project is to develop an IGFC technology that can be scaled up for $500 \mathrm{~kW}$ system demonstration.

The successful development of an IGFC system will ensure that coal can continue to be used as one of the key energy resources in China in the next couple of decades, before renewable energy becomes the dominant energy source. In the future, traditional coal-fired power plants can be replaced by efficient 100 MW IGFC power generation systems with near-zero carbon emissions.

\section{Introduction: IGFC project}

\subsection{Objectives}

The objectives of the IGFC project are to develop IGFC technology with a $\mathrm{CO}_{2}$ capture or utilization subsystem, using coal syngas as fuel and a high-temperature fuel cell to replace the gas turbine in an IGCC to convert chemical energy to electrical energy directly, which is scalable to larger system, and meanwhile generate intellectual property portfolios for key technologies. At the end of the project, it is intended that a $1 \mathrm{MW}_{\mathrm{th}}$-level (input heat value) IGFC demonstration system with near-zero $\mathrm{CO}_{2}$ emission will be designed, built, and operated, with $\mathrm{CO}_{2}$ capture rate $\geq 91 \%$ and fuel cell power generation efficiency $\geq 50 \%$. Based on this technology, a blueprint design of a 100-MW-class IGFC power plant will be developed and analyzed, with the expected target of achieving $\mathrm{CO}_{2}$ capture rate $\geq 90 \%$, fuel cell power efficiency $\geq 50 \%$, and overall system efficiency $\geq 47 \%$.

Successful completion of the project will help to understand better the design principles and process and engineering optimization of IGFC systems, including all the subsystems, accelerate the commercialization of IGFC technology in China, and eventually achieve the target of $\mathrm{CO}_{2}$ reduction in the next few decades, which is a revolutionary change from coal-based power generation. Meanwhile, the project will attract private investment to support fundamental research and technology development, which can further improve the performance, cost reduction, long-term durability, and reliability of the IGFC system.

\subsection{Scope of the work}

The project is focusing on areas of coal gasification and syngas purification, high-temperature fuel cell stacks and module design, $\mathrm{CO}_{2}$ capture and utilization, and IGFC system design and engineering optimization.

This project comprises five tasks: (1) investigation of the effect of energy conversion and the operation conditions of subsystems on the efficiency of the IGFC system; (2) development of new gasifier and syngas purification equipment and investigation of contaminant formation during coal gasification; (3) technological development of a high-temperature fuel cell power generation system using coal syngas as fuel; (4) investigation of the method of $\mathrm{CO}_{2}$ capture and utilization for IGFC systems; (5) demonstration of a $\mathrm{MW}_{\text {th }}$ IGFC power generation system with nearzero $\mathrm{CO}_{2}$ emission. Tasks 2 to 4 provide technical support and the guidelines for IGFC system design, performance, and operation under task 5 . Task 1 is focused on conceptual design, system performance evaluation, and technology scale-up, based on the IGFC system developed under task 5.

\subsection{Initial concept of the IGFC system}

The IGFC system to be developed consists of three subsystems: (1) coal gasification and syngas purification, to remove different kinds of impurity and obtain high-quality syngas, a mixture of $\mathrm{H}_{2}$ and $\mathrm{CO}$, which may go through a water-gas shift reactor to convert $\mathrm{CO}$ into $\mathrm{CO}_{2}$ before entering the fuel cell stacks; (2) high-temperature fuel cell stacks, to directly convert the chemical energy of the fuel to electricity, with air going into the cathode side and fuel going into the anode side, and oxygen being reduced to oxygen ions on the cathode side, which are then transported through the electrolyte to the anode side and react with $\mathrm{H}_{2}$ to form water (as steam) on the anode side; and (3) combustion of outlet fuel from the fuel cell stack via an oxygen combustor to enrich $\mathrm{CO}_{2}$ for capture and storage or utilization through co-electrolysis of $\mathrm{CO}_{2}$ and $\mathrm{H}_{2} \mathrm{O}$ in a solid oxide electrolysis cell (SOEC). The process for the IGFC system is shown in Fig. 1. 


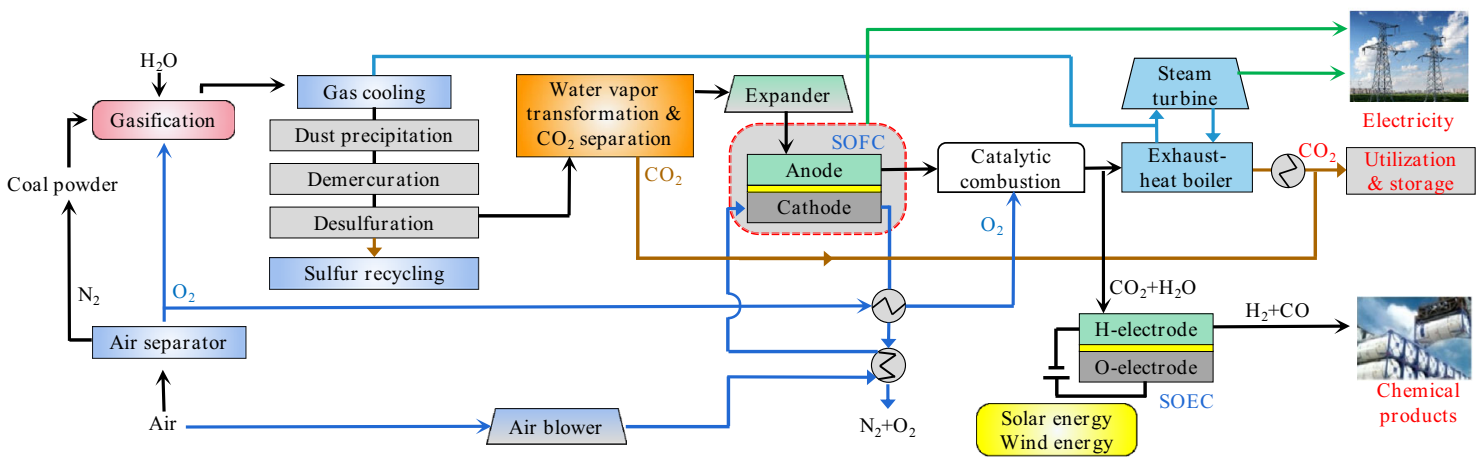

Fig. 1 IGFC system to be developed

\section{Major progresses of IGFC project}

\subsection{Coal gasification purification}

To develop new technology for coal gasification and syngas purification, the gasification reaction characteristics of ultrafine coal char particles, the effect of the melting of coal ash on the coal gasification reaction, models to predict the coal gasification processes, the formation mechanism of syngas contaminants, and the pressure-swing adsorption separation of $\mathrm{H}_{2} \mathrm{O}$ and $\mathrm{CO}_{2}$ from syngas at elevated temperatures were studied. The process, from coal to $\mathrm{H}_{2}$, is shown in Fig. 2.

(1) The method of desulfurization and decarburization using activated carbon at moderate temperatures was selected. The effects of reaction temperature, regeneration method, water vapor content, and water-gas conversion reaction on desulfurization and decarburization were investigated. The desulfurization and decarburization performance using activated carbon adsorbent was also studied by simulating the actual composition, and the macroscopic phenomena observed were explained using microscopic mechanisms. Carbon dioxide can be separated from cleaned syngas, for utilization and storage, through the bypass line after the water-gas shift reactor for $\mathrm{CO}_{2}$ scrubbing in the IGFC system, as shown in Fig. 1.

(2) An experimental device for mercury removal was set up and mercury removal adsorbents were selected. Aluminum oxide powder with internal micropores and a particle size of $1.00-0.55 \mathrm{~mm}$ (specific surface area, $240 \mathrm{~m}^{2} / \mathrm{g}$ ) and cobalt nitrate were used as the carrier and active component of the adsorbent, respectively. The $\mathrm{Al}_{2} \mathrm{O}_{3}$ powder was first impregnated with $10 \mathrm{wt} \%$ cobalt nitrate and $10 \mathrm{vol} \%$ hydrochloric acid solution and then calcined in a nitrogen atmosphere at $500{ }^{\circ} \mathrm{C}$ for $2 \mathrm{~h}$. The experimental results showed that an efficiency of mercury removal of up to $90 \%$ could be achieved.

(3) The enrichment or dissociation characteristics of inorganic mineral elements, nitrogen, and sulfur in ultrafine coal particles were analyzed. A kinetic study of the gasification reaction of ultrafine coal particles was conducted. A method for calculating gasification reaction dynamics was established, and kinetic parameters, such as reaction rate, activation energy, and pre-exponential factor of $\mathrm{CO}_{2}$ gasification of ultrafine coal particles at different reaction temperatures and different particle size distributions,

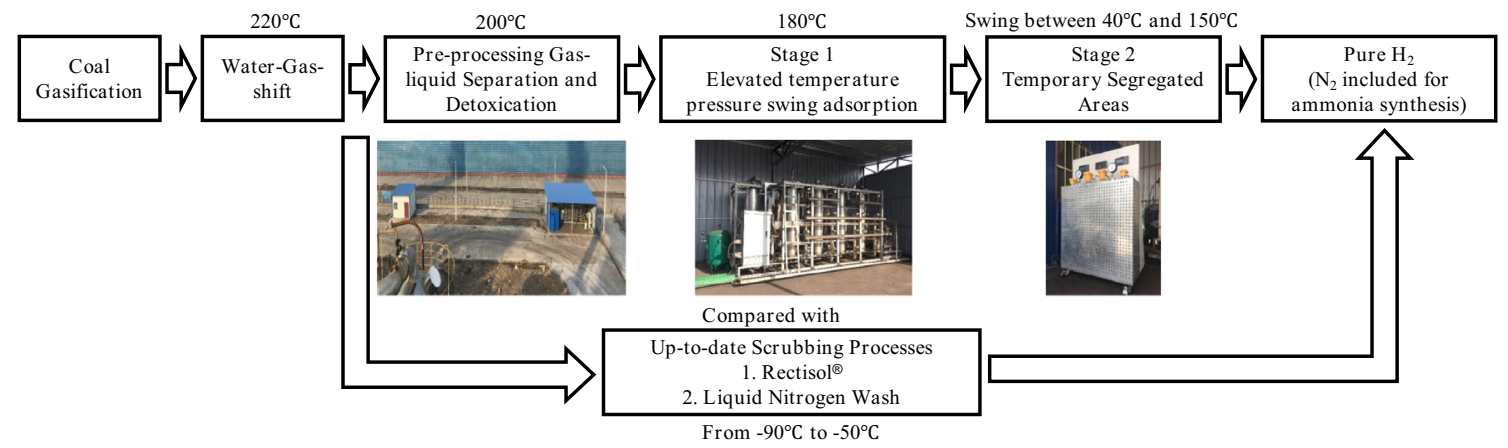

Fig. 2 Overall process from coal to $\mathrm{H}_{2}$ in the ammonia plant 
were obtained. The effect of ash melting on coal gasification was also investigated.

(4) A kinetic model for $\mathrm{CO}_{2}$ gasification of ultrafine coal particles was developed, and an experimental scheme for coal gasification was established. The kinetic parameters of coal gasification at high temperatures were obtained, from which a distributed activation energy model was established, and the dynamic characteristic parameters were analyzed.

\subsection{High-temperature fuel cell}

The $5 \mathrm{~kW}$ SOFC and 10-20 kW MCFC stacks were tested. Research on the integrated coupling mode and control strategy of $100 \mathrm{~kW}$ SOFC and MCFC systems has started, and the design scheme has been optimized. The main progress of the high-temperature fuel cell is summarized as follows.

(1) Based on performance data of the stack, a multiphysical field coupling model of the electric, temperature and flow fields within the SOFC stack was constructed, and the stack design was optimized. Kilowatt-level stacks have operated for more than $1200 \mathrm{~h}$ with syngas $\left(\mathrm{H}_{2}, 69.87 \%\right.$; $\mathrm{CO}, 19.48 \% ; \mathrm{CH}_{4}$, $0.29 \% ; \mathrm{CO}_{2}, 10.36 \%$ ), and the output power was stable at above $725 \mathrm{~W}$. A design concept of a 10-25 kW SOFC power generation system (Fig. 3) based on syngas has been completed. The balance of plant of the power system was built and installed, and the stack module is being assembled at the test site. Commissioning tests will begin soon.

(2) The design of a $5 \mathrm{~kW}$ MCFC short stack has been finalized. Material compatibility for scaling up components, such as the MCFC matrix, electrode, and bipolar plate, was optimized, and satisfactory results were achieved. Short stacks of MCFCs with a cell area of $0.2 \mathrm{~m}^{2}$ were successfully fabricated. The discharge current densities of up to $110 \mathrm{~mA} / \mathrm{cm}^{2}$ at constant voltage were obtained for a single cell and 10 short stacks of MCFCs. A long-term durability test of 10 short stacks demonstrated relatively stable performance over $960 \mathrm{~h}$. Using a single MCFC, the effect of syngas composition and impurities on cell performance was studied. Based on the test matrix and the results, the design operation conditions of the MCFC stack were selected. Recently, a $20 \mathrm{~kW}$ MCFC single stack (Fig. 4), with a maximum power output of $21.6 \mathrm{~kW}$, was built and tested, and a stable power output of $16.51 \mathrm{~kW}$ was achieved. The start-up procedures, which were determined and optimized using short stacks, were

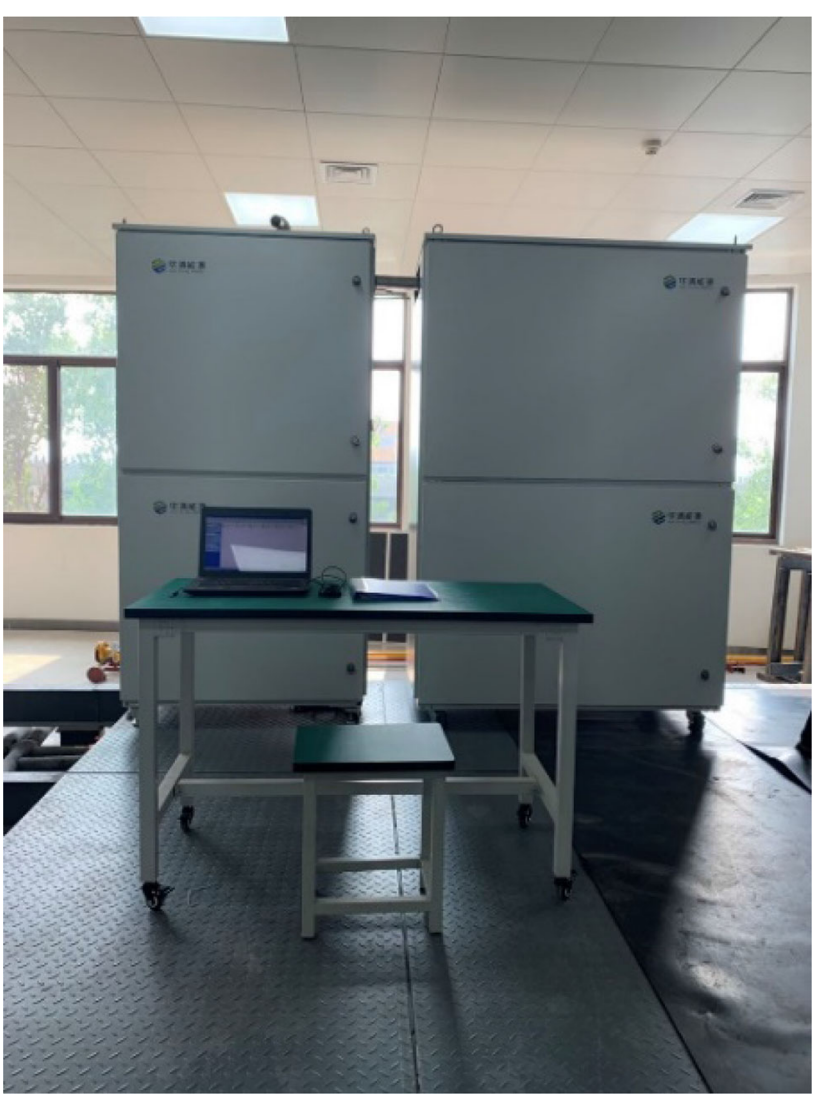

Fig. $310 \mathrm{~kW}$ SOFC system

implemented into a $20 \mathrm{~kW}$ stack; this ensured mechanical integrity of the stack for improved performance.

(3) The initial concept design of the $100 \mathrm{~kW}$ MCFC power generation system and its control strategy was completed. The materials and components for cell and stack fabrication to construct a $100 \mathrm{~kW}$ MCFC system were ordered.

\section{3 $\mathrm{CO}_{2}$ capture and energy conversion}

In accelerating the development of carbon capture, utilization and storage technology is essential for the development of advanced IGFC technology with near-zero $\mathrm{CO}_{2}$ emissions. In this stage, new methods of $\mathrm{CO}_{2}$ capture and energy conversion will be explored for off-gas from a hightemperature fuel cell. Two technologies, catalytic combustion and co-electrolysis of $\mathrm{CO}_{2}$ and $\mathrm{H}_{2} \mathrm{O}$ via SOECs, are being developed. The objectives of this task are to develop a kilowatt-level SOEC stack for co-electrolysis of $\mathrm{CO}_{2}$ and $\mathrm{H}_{2} \mathrm{O}$ and build an experimental test rig to verify the catalytic combustion technique. The lessons learned from laboratory-scale testing will help the team scale up the SOEC stack and combustor technology and implement 


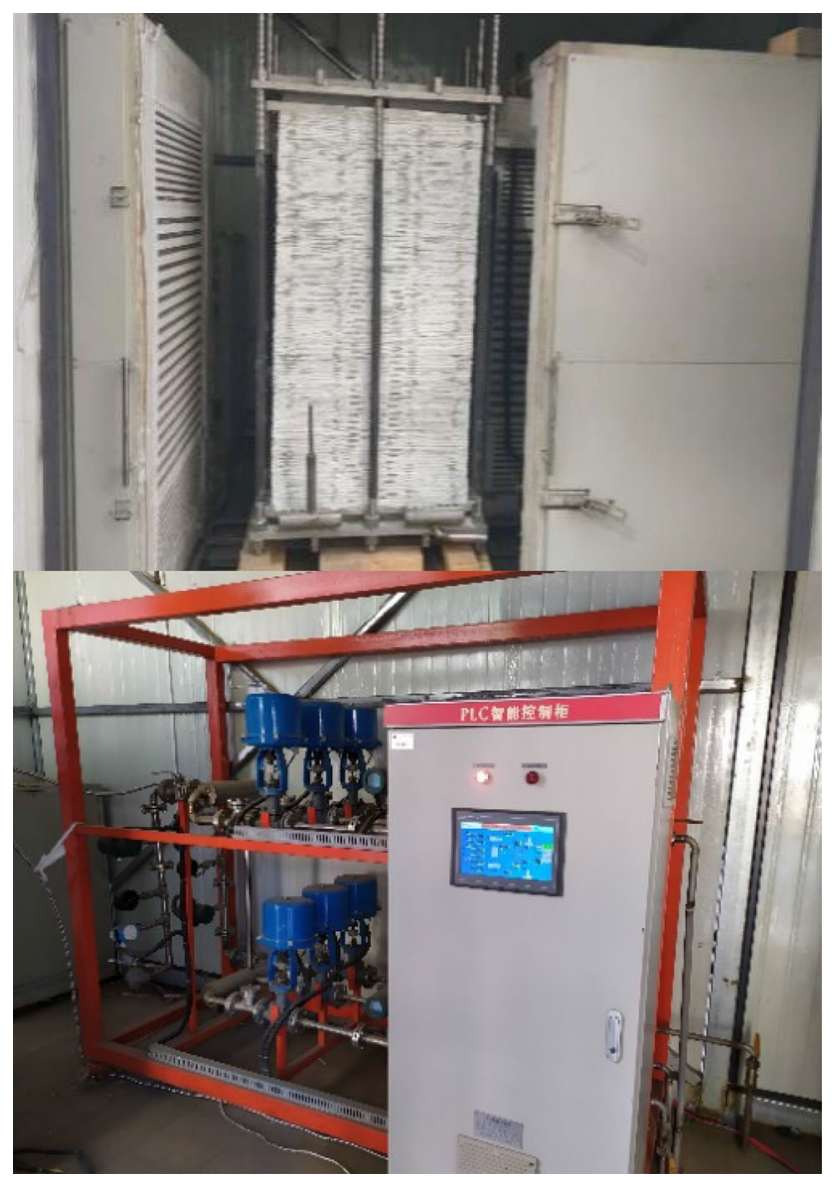

Fig. $420 \mathrm{~kW}$ MCFC single stack

them in a $\mathrm{MW}_{\text {th }}$ IGFC demonstration system. The main progress made in this task is described next.

(1) Exhaust gas catalytic combustion technology: Water-and- $\mathrm{CO}_{2}$ resistant perovskite and hexaaluminate catalysts for fuel cell off-gas combustion were successfully developed and deposited on a porous ceramic substrate, from which a kilowatt-class SOFC off-gas burner and a testing system were built. The simulated conversion rate of the combustible components $\left(\mathrm{CO}, \mathrm{H}_{2}\right)$ of exhaust gas is $>97 \%$, as verified by experimental data.

(2) Multidimensional model construction and internal heat and mass transfer mechanism: One-dimensional, quasi-two-dimensional, and three-dimensional SOFC-SOEC stack models were developed, and the effects of the cathode side flow channel and its structure on stack performance were analyzed. The effects of operating parameters, such as conversion rate of $\mathrm{CO}_{2}$, on the co-electrolysis reaction of $\mathrm{CO}_{2}$ and $\mathrm{H}_{2} \mathrm{O}$ in the SOEC stack, were investigated, and strategies for further optimization were proposed. From the theoretical model and experimental results, the mechanism of $\mathrm{CO}_{2}$ reduction and conversion to $\mathrm{CO}$ in a SOFC-SOEC stack was better understood.

(3) Materials, cell, and stack technology development of SOECs (Fig. 5): New perovskite electrode materials were developed through in situ precipitation of nanoparticles, and showed good catalytic activity for $\mathrm{CO}_{2}$ reduction and conversion to $\mathrm{CO}$ in SOEC cells or stacks. Using new electrode materials, SOFCs and SOECs were successfully fabricated with good quality and high yield, and were also scaled up to produce full-size rectangular cells for stack development. A unique stack design with an open-cathode structure was developed, and can be integrated to produce larger SOFC-SOEC modules for power generation or as electrolysis. A number of kilowatt-

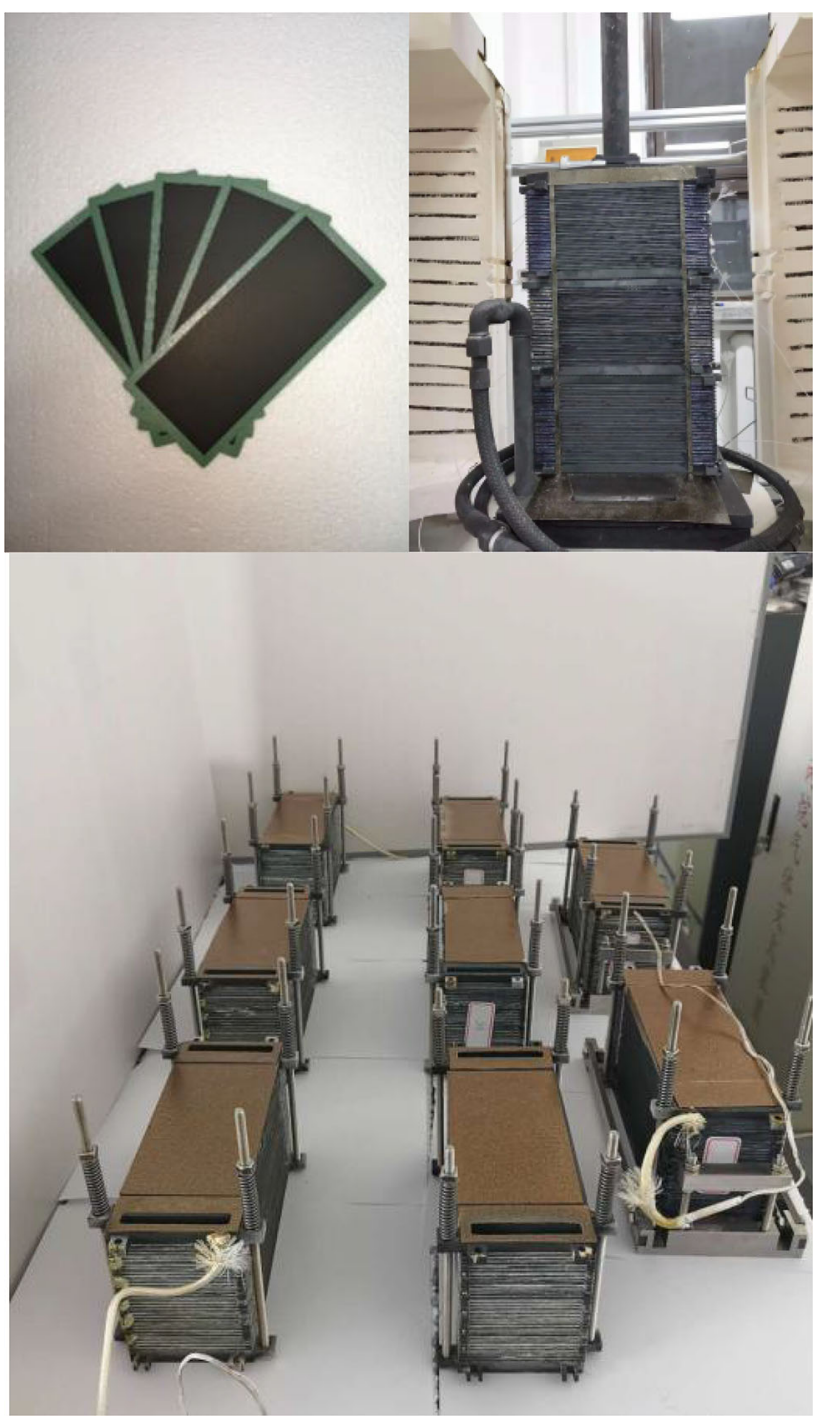

Fig. 5 Single cell, stack, and standardized large-scale assembly of SOEC stacks 
level stack tests demonstrated high power output and stable performance. (Fig. 6).

\subsection{Demonstration of IGFC system}

Comprehensive economic analysis of a typical IGFC system was performed and the results were compared with those obtained for a supercritical pulverized coal-fired (SCPC) power plant, demonstrating that the cost of electricity of IGFC could be up to $20 \%$ less than that for a SCPC with $\mathrm{CO}_{2}$ capture. The SOFC stacks selected for IGFC development were tested under both hydrogen and simulated coal syngas fuel, showing good consistency and stable long-term performance. Experimental results using SOFC stacks and thermodynamic analysis (using Aspen Plus) indicate that the hydrogen to $\mathrm{CO}$ ratio of the syngas is preferably 1.68 or higher, to avoid carbon deposition inside the fuel pipe. For a lower $\mathrm{H}_{2}$ : $\mathrm{CO}$ ratio, the steam to $\mathrm{CO}$ ratio needs to be higher. Moreover, the steam needs to be mixed well with the syngas above $100{ }^{\circ} \mathrm{C}$ and below the temperatures where carbon formation is
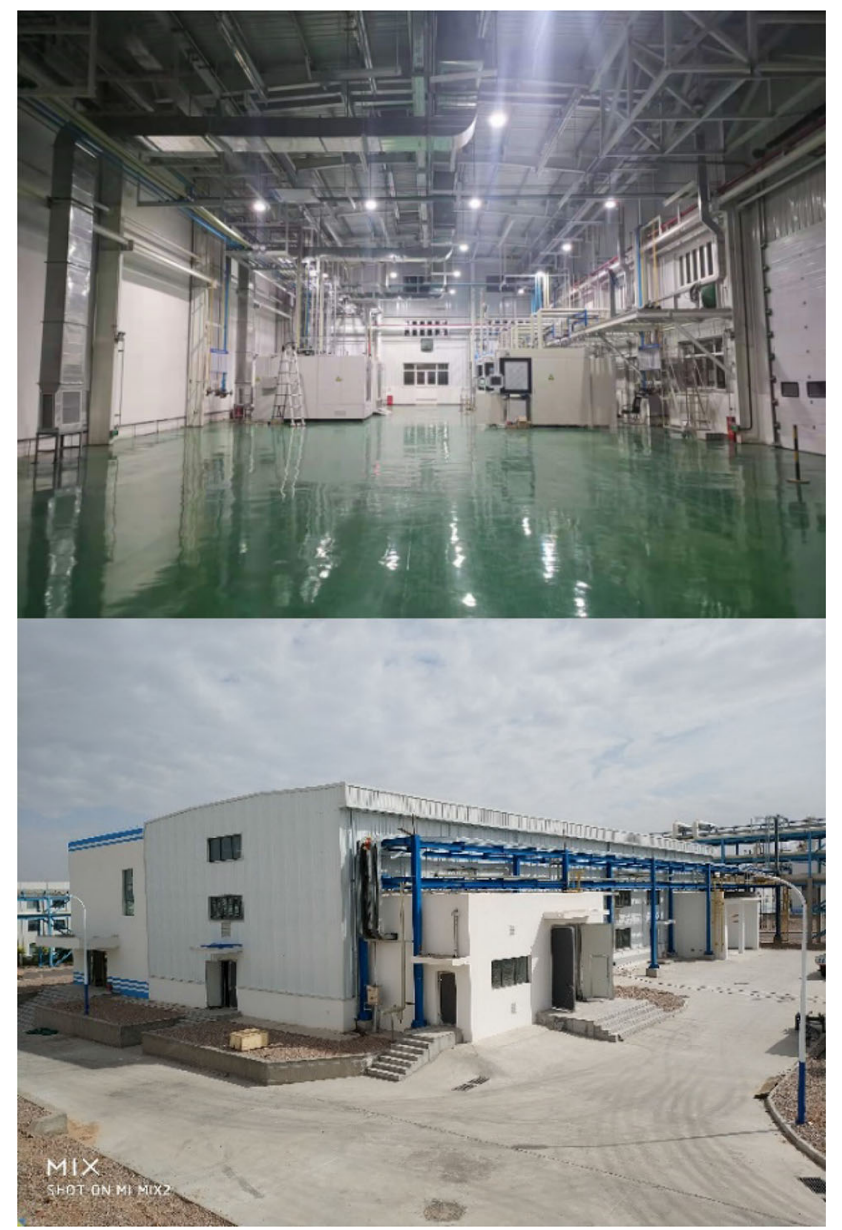

Fig. 6 IGFC test platform and demonstration base thermodynamically favored. A $20 \mathrm{~kW}$ SOFC power generation unit is being developed with a design system condition of $20 \mathrm{~kW}$ maximum power, current density of 0.334 $\mathrm{A} / \mathrm{cm}^{2}$, DC efficiency of $50.41 \%$, and fuel utilization of $80 \%$. A $100 \mathrm{~kW}$ level subsystem will consist of six $20 \mathrm{~kW}$ power generation units, and the $\mathrm{MW}_{\text {th }}$ IGFC system will consist of five $100 \mathrm{~kW}$ level subsystems.

\section{Conclusions}

A dry method for sulfur-carbon co-decoupling from coal syngas at moderate temperatures was developed and an experimental device for syngas purification was built and tested. The results show that the total sulfur content in the purified gas is less than $0.02 \mathrm{ppm}$. A $5 \mathrm{~kW}$ SOFC and a 20-kW-class MCFC stack were assembled. The MCFC stack was tested continuously for $72 \mathrm{~h}$ with a stable power output of $>16.5 \mathrm{~kW}$. Full-size cells were developed, and a kilowatt-class SOEC stack was assembled and tested. High-efficiency $\mathrm{CO} 2$ conversion was achieved. The preliminary design of the 20-kW-class SOFC power generation unit was completed. The design of the testing site for MWth IGFC system demonstration has just been completed, and the site preparation and construction will start in next couple of months.

During this project, it was demonstrated that IGFC systems are capable of reducing $\mathrm{CO} 2$ emissions. The hightemperature fuel cells have demonstrated the feasibility of achieving high power efficiency with traditional fuel. It is expected that in the near future, the coal-fed IGFC will be one of the most promising clean and low-cost energy sources.

Acknowledgements This work was financially supported by the National Key R\&D Program of China (2017YFB0601900).

Open Access This article is licensed under a Creative Commons Attribution 4.0 International License, which permits use, sharing, adaptation, distribution and reproduction in any medium or format, as long as you give appropriate credit to the original author(s) and the source, provide a link to the Creative Commons licence, and indicate if changes were made. The images or other third party material in this article are included in the article's Creative Commons licence, unless indicated otherwise in a credit line to the material. If material is not included in the article's Creative Commons licence and your intended use is not permitted by statutory regulation or exceeds the permitted use, you will need to obtain permission directly from the copyright holder. To view a copy of this licence, visit http://creativecommons. org/licenses/by/4.0/.

\section{References}

Bhanarkar AD, Gavane AG, Tajne DS, Tamhane SM, Nema P (2008) Composition and size distribution of particules emissions from a coal-fired power plant in India. Fuel 87:2095-2101 
Campanari S (2002) Carbon dioxide separation from high temperature fuel cell power plants. J Power Sources 112:273-289

Chang SY, Zhou JK, Meng S, Qin SY, Yao Q (2016) Clean coal technologies in China: Current status and future perspectives. Engineering 2:447-459

Chen SY, Lior N, Xiang WG (2015) Coal gasification integration with solid oxide fuel cell and chemical looping combustion for highefficiency power generation with inherent $\mathrm{CO}_{2}$ capture. Appl Energy 146:298-312

Damo UM, Ferrari ML, Turan A, Massardo AF (2019) Solid oxide fuel cell hybrid system: A detailed review of an environmentally clean and efficient source of energy. Energy 168:235-246

Discepoli G, Cinti G, Desideri U, Penchini D, Proietti S (2012) Carbon capture with molten carbonate fuel cells: Experimental tests and fuel cell performance assessment. Int J Greenhouse Gas Control 9:372-384

Surdoval W, Singhal S, McVay G (2001) The Solid State Energy Conversion Alliance (SECA) - A U. S. Department of energy initiative to promote the development of mass customized solid oxide fuel cells for low-cost power. Proc 16:53-61

Dong BQ, Li CF, Liu CL, Huang B, Wang Q, Fan WP, Li PP (2019) Integrated gasification fuel cell power generation technology with $\mathrm{CO}_{2}$ near zero emission and its challenges. Coal Sci Technol 47:189-193

Gräbner M (2015) Industrial coal gasification technologies covering baseline and high-ash coal. Wiley, Weinheim

Hui Y (2015) Research of integrated gasification combined cycle power generation system. Chem Eng Equip 2:155-157

Jiao SJ (2009) Review and prospect of the development of IGCC technology. Electr Power Constr 30:1-7

Li M, Rao AD, Brouwer J, Samuelsen GS (2010) Design of highly efficient coal-based integrated gasification fuel cell power plants. J Power Sources 195:5707-5718
Li M, Rao AD, Samuelsen SG (2012) Performance and costs of advanced sustainable central power plants with $\mathrm{CCS}$ and $\mathrm{H}_{2}$ coproduction. Appl Energy 91:43-50

Li PP, Liu CL, Huang B, Fan WP, Wang Q, Li CF, Surinder S, Ba LM (2018) Process simulation and energy analysis for IGFC system. Comput Appl Chem 35:988-996

Lv YK, Dou ZZ, Zhao K (2010) IGCC power plant with energy conservation. Appl Energy Technol 10:36-39

Mao XQ, Zeng A, Hu T, Xing YK, Zhou J, Liu ZY (2014) Co-control of local air pollutants and $\mathrm{CO}_{2}$ from the Chinese coal-fired power industry. J Cleaner Prod 67:220-227

Mastropasqua L, Campanari S, Brouwer J (2017) Solid oxide fuel cell short stack performance testing - part B: Operation in carbon capture applications and degradation issues. J Power Sources 371:238-248

Peng S, Han M (2009) Development of coal/carbon based solid oxide fuel cell. Chin J Nat 31(4):187-192 ((in Chinese))

Shindo A (2017) Up-to-date clean coal technology for future power generation and its roadmap of Japan. In: 8th International Forum on Energy for Sustainable Development.

US Department of Energy (2019) Department of Energy announces $\$ 100 \mathrm{M}$ in investments in Coal FIRST. ENERGY.GOV. https:// www.energy.gov/articles/department-energy-announces-100minvestments-coal-first. Accessed 12 April 2019.

Wang HL, He XY, Liang ZX (2015) A comparative analysis of the post-2020 $\mathrm{CO}_{2}$ emission reduction target set by China and the United States. China Popul Resour Environ 25:23-29

Williams MC, Strakey J, Wayne S (2006) U.S. DOE fossil energy fuel cells program. J Power Sources 159:1241-1247 